\title{
A Feitoria Portuguesa do Rio de Janeiro
}

Fernando Lourenço FERNANDES ${ }^{*}$

Resumo: $O$ artigo aborda a investigação sobre o local onde foi erguida a primeira feitoria portuguesa no Brasil, o primeiro núcleo de civilização européia ao sul do equador, no Atlântico Ocidental. Discutindo as teses sobre a denominada feitoria de "Cabo Frio" (Varhagen e Laguarda Trias), o texto examina o elenco de fatores geológicos, etnológicos, iconográficos e cartográficos implicados, à luz de elementos probatórios históricos e arqueológicos, para sustentar a localização da feitoria na ilha do Gato, a ilha do Governador da Baía de Guanabara. Indícios de um provável pré-descobrimento do Brasil rondam o ensaio, com a reinterpretação das circunstâncias nebulosas que envolvem o chamado "ciclo do pau brasil".

Palavras-Chave: Feitoria portuguesa; Varhagen; Laguarda Trias.

\section{1 - Introdução}

Os Abrolhos constituem uma larga região marítima ao sul da Bahia, onde se situam o arquipélago de cinco ilhas (Santa Bárbara, Guarita, Redonda, Siriba e Sueste, cerca de 80 quilômetros do litoral na altura de Caravelas), o parcel dos Abrolhos, a leste do conjunto insular, os recifes Timbebas a noroeste e, mais adiante, o parcel das Paredes. Mar perigoso que já engolfou um número sem conta de embarcações, vinha

* Advogado e publicista. Membro do Instituto Histórico e Geográfico do Distrito Federal e da Academia de Marinha, Lisboa. Ao longo dos anos, vem realizando pesquisas e publicando trabalhos sobre as navegações no Atlântico Sul durante o século XV e começo do XVI." Email: fernandes-fl@uol.com.br

HISTÓRIA, São Paulo, 27 (1): 2008 
assinalado pelos navegadores portugueses do século XVI com o alerta orientador: "Abre os olhos".

As aproximações da costa, a partir daí, eram cautelosas e temerários os que não rumavam abertos para oriente. Os Abrolhos representavam, portanto, um marco divisor nos rumos do Atlântico meridional brasileiro, mas não parece remanescer dúvida de que o início da atividade de feitorias, com o aproveitamento da flora e da fauna utilitária - notadamente do pau-brasil - se dá ao sul dessa linha de perigos para a navegação.

Se há notícias de presença lusa em Porto Seguro, desde muito cedo após a passagem da esquadra de Pedro Álvares Cabral, as anotações atribuídas a Vespucci pareceram, a Varnhagen, definir Cabo Frio como a sede escolhida para o estabelecimento, no esquema da viagem de 1503.

Consoante a tradição histórica, o pau-brasil (PB) foi encontrado sem maiores dificuldades no litoral da Vera Cruz em 1500, logo após o desembarque de Cabral e o tema da madeira de tinta, desprovido de importância, acabou deixado para trás. Os conteúdos da historiografia dedicados ao pau-brasil (PB) exibem, salvo raríssimas exceções, a manifestação de um conhecimento tão convencional quanto repetitivo. Embora um diminuto e importante elenco de obras, na bibliografia ${ }^{1}$, tenha deixado o caminho aberto para novas e complementares pesquisas e para o desdobramento do tema nos diversos enfoques disciplinares que implica, nem por isto o assunto logrou animar o cenário acadêmico.

Se o assunto pau-brasil (PB) era considerado esgotado e sem maiores possibilidades de produzir dividendos para a historiografia, também há não muito tempo atrás, o da feitoria portuguesa achava-se jungido ao que poderia ser chamado de modelo Varnhagen: atribuição da iniciativa a Vespucci e localização no litoral fluminense, em Cabo Frio, o que se coadunava com o local onde em 1511 a nau Bretoa encostara para tomar sua carga de pau-tinta. 
Os trabalhos de Jaime Cortesão, Avelino Teixeira da Mota e Duarte Leite - na vertente portuguesa de pesquisa puderam, então, clarear o cenário histórico das primeiras explorações à costa brasileira, fazendo alguma luz sobre o tema das feitorias, este, uma derivada daquelas. Sucederamse os estudos de Max Justo Guedes, os quais agregaram ao exame crítico diplomático e das fontes narrativas, a análise dos condicionalismos físicos do Atlântico e o congresso de toda a documentação cartográfica disponível, esta última, fator probatório de relevância. Com isto, produziu-se uma avaliação interativa e mais confiável, sobre o reconhecimento do litoral brasileiro.

Contudo, em 1971, Rolando Laguarda Trías deu a conhecer importante comunicação no II Colóquio Luso-Brasileiro de História do Brasil, conclave realizado em Lourenço Marques, como era denominada, então, a capital de Moçambique. "Neste notável trabalho, o erudito historiador apresentou hipótese inteiramente nova sobre a localização da feitoria de Cabo Frio. A referência ao cabo, segundo Trías, seria apenas geográfica, por ser ele o mais conhecido acidente da costa meridional brasileira. $\mathrm{Na}$ realidade, a feitoria situar-se-ia na atual baía de Guanabara (Rio de Janeiro)", comentou Max Guedes, sublinhando o caráter altamente convincente da documentação apostada e dos argumentos levantados pelo estudioso uruguaio. ${ }^{2}$ No desenrolar da edição da monumental História Naval Brasileira, Laguarda Trías teve a oportunidade de colaborar em seu texto, o que valeu para ampliar a divulgação da tese inovadora.

Partindo do episódio da nau Bretoa que em 1511 encostara em Cabo Frio para carregar pau-brasil (PB) - episódio que levou Varnhagen às conclusões mencionadas sobre o posicionamento geográfico da feitoria - o pesquisador enveredou por uma bem esmiuçada investigação, onde o eixo da enquête girou em torno do piloto João Lopes de Carvalho, deixado naquela costa, «apesar de seus protestos de inocência, por haver subtraído uns machados". 
No relato de Ginés de Mafra, colheu a afirmação de que Juan Caravallo, piloto de Fernão de Magalhães, havia vivido na baia de Henero, ou seja, na baía de Guanabara, o Rio de Janeiro, "e ali deixado um filho que em 1519» - quando da passagem da frota castelhana - "tinha sete anos de idade, o que equivale dizer que havia nascido em 1512». Portanto, Juan Caravallo, não era outro se não João Lopes de Carvalho, da nau Bretoa, com um filho nascido em 1512 (e gerado em 1511). O piloto foi reconhecido pelos indígenas da baía de Guanabara que acolheram a frota espanhola e logo trouxeram a mãe e o menino para bordo, entregando-o ao pai.

Em Pigaffeta encontrou Laguarda Trías a confirmação da estada de João de Carvalho - aliás, o João Carnagio do texto em terras brasileiras, centrada a referência na obra do Visconde Lagoa.

A arregimentação de Carvalho em Sevilha e seu embarque na companhia de Magalhães, a cronologia dos eventos desde 1511, o rumo que deu à armada diretamente ao Rio de Janeiro e a autorização obtida do Comandante para a recolha da criança, tudo isto demonstrou, consoante o pesquisador, que a feitoria para o comércio do pau-brasil se encontrava na baía do Rio de Janeiro, pois o capitão da Bretoa, com o fim de castigar João Lopes de Carvalho, não iria levantar âncora de Cabo Frio simplesmente para deixar o condenado na baía de Guanabara, retornando a seguir a Cabo Frio, antes de partir para Portugal. O diário de viagem da nau Bretoa não alude à tal cabotagem pela costa fluminense. $\mathrm{E}$ conclui $\mathrm{O}$ historiador uruguaio, que a situação da feitoria se mantinha oculta com o fim lógico de neutralizar a ameaça "de um possível saque e destruição do estabelecimento, como ocorreu com a de Pernambuco, em 1531 e 1532». ${ }^{3}$

Como já foi dito, a menção ao Cabo Frio, seria apenas de natureza geográfica, um marcante acidente da costa assinalando a brusca modificação da linha litorânea que passa a correr, naquela altura, de leste para oeste. 
Poderiam os argumentos de Laguarda Trías ser examinados à luz de outras fontes ou de outras metodologias de pesquisa?

Não obstante, uma outra questão reclama estudo preliminar. Por que os portugueses iriam procurar o assentamento da feitoria ao sul dos Abrolhos, quando o litoral do nordeste brasileiro era muito mais acessível, demandando travessias mais curtas e com o produto tintorial tão bom ou de melhor qualidade que o de Cabo Frio ? Que pressupostos náuticos, políticos e estratégicos poderiam quadrar a tese da localização meridional da escápula do pau-brasil, seja no modelo Varnhagen, seja na visão retificadora de Laguarda Trias?

\section{2 - Ao Sul dos Abrolhos}

O Brasil tem um início de história contado por naus, quando deveria ter sido contado por caravelas. A começar pelo cruzeiro de arribada da frota de Cabral - com as singelezas do percurso até o Porto Seguro - à viagem da Bretoa, são naus a se destacarem no proscênio dessa história. Faltam as caravelas, as indagadoras, as "farejadoras" dos meandros, dos baixios, as rastreadoras dos obstáculos escondidos no mar costeiro, as desenhadoras de caminhos marítimos, depois e atrás das quais poderiam vir as naus.

Tanto quanto os descobrimentos ou os "pontos de chegada", os itinerários são importantes para entender o nexo da história ali contido. E para desvendá-la.

Em algum momento após a expedição africana de Bartolomeu Dias (1488) em demanda do cabo das Tormentas, quando chegou ao rio do Infante, no Índico, iniciaram-se viagens de reconhecimento a oeste, no Atlântico Sul, "com o propósito de determinar a rota que, pelo sudoeste, conduzisse em melhores condições ao Cabo da Boa Esperança". ${ }^{4}$ Neste caso, o acesso às costas brasileiras teria ocorrido, com toda a probabilidade, em tais viagens. O regime de ventos do Atlântico Sul, no somatório dos elementos determinantes do 
condicionalismo físico da região, com o domínio das técnicas de navegação à vela, facultava sem maiores dificuldades, a abertura de rotas exploratórias nas direções oceânicas do sudoeste e oeste. ${ }^{5}$

As viagens exploratórias poderiam ter suas largadas em qualquer das posições detidas pelos portugueses na costa ocidental da África ao sul do equador, com o recurso de dar a bordada para ir buscar, entre julho e setembro, o vento geral do sueste, nas águas favoráveis da Corrente Equatorial Sul. A ilha de São Tomé estaria, então, a 15 ou 20 dias de viagem ao Brasil, numa navegação fácil, tranqüila. ${ }^{6}$

As instruções de Vasco da Gama a Pedro Álvares Cabral recomendam a "volta do mar" - a grande linha curva para os lados do Brasil - com os sopros do geral de sueste, até quando o cabo da Boa Esperança estiver em leste franco, "porque nessa latitude, depois de vencida a costa do Brasil, o vento será sempre mais largo, permitindo fazer a derrota direta, já sem a preocupação de ir à bolina cerrada".

Vale recordar que após a vigência do Tratado de Tordesilhas, com as alterações à anterior linha divisória dos interesses geográficos portugueses e castelhanos, e a adoção de uma raia vertical, o meridiano das 370 léguas a oeste do arquipélago de Cabo Verde, o conceito do que poderia ser qualificado como zonas de incorporação ibérica, carecia de efetivo desenho, e "mais do que uma rota marítima que se pretende reservar, é um espaço que se procura definir", conforme observou Luís Adão da Fonseca. ${ }^{8}$

A conseqüência da definição da rota de melhor franqueamento da passagem do cabo da Boa Esperança e, em um dado momento, do acesso a uma zona territorial (além de marítima) nos limites meridionais da linha de Tordesilhas, impunha não apenas um reconhecimento e exploração desses mares tropicais ao sul dos Abrolhos - nas alturas do leste franco para o Índico - como a presença lusa na costa lindeira, mais importante ainda quando, muito cedo, ficou patente a existência aí de pau-brasil, por si só um fator potencial para eclosão de problemas. 
A apreciação das viagens exploratórias portuguesas durante o século XV tem encontrado, no mais das vezes, o aprofundar de análises centradas no saber marítimo conquistado ao longo das décadas de esforço progressivo, de sua vez refletido, a partir dos avanços nos campos da ciência e tecnologia náuticas, na representação cartográfica. Entretanto, a representação da Terra se deu também na forma de outros desdobramentos da observação, ou seja, da descrição dos litorais, de seus habitantes, sua fauna, flora e clima, suas características fisiográficas, enfim, do ambiente encontrado.

Assim, para lá da arquitetura naval, do rotear, das inovações bélicas, da marinharia e da revolução cartográfica, um tópico de pesquisa que se pode associar ao estudo das viagens, é o conhecer das terras que se vão alcançando com as navegações e a maneira de atingi-las, seja para o retorno, ainda que com cautelas, seja para deixá-las ao largo. Isto conduz a dois conceitos reciprocamente excludentes no projeto de navegação português e que aqui se pode formular: áreas de atração, onde se compadeciam as condições de utilidade para os diversos itens da política ultramarina - seja como pontos de apoio, seja como o próprio alvo ou objetivo a ser atingido - e zonas de exclusão no percurso das rotas, as quais pelos mais variados motivos seriam evitadas.

De qualquer forma, o ponto conspícuo para o acesso à costa meridional brasileira, de quem vem rumado pela Corrente do Brasil e logo após dobrar os baixos dos Abrolhos, era o Espírito Santo. Confirmada pela sonda de 40 e 50 braças a ultrapassagem daquela latitude, um veleiro em demanda do litoral iniciava a busca das marcas de aterragem e, livrados os rasos dos Pargos ou dos Parguetes, na região do cabo de São Tomé, entrava à procura do Cabo Frio (ou, mais adiante, da ilha de São Sebastião), o ponto referencial de destaque para ingressar nos ancoradouros do Sul, Rio de Janeiro, Angra dos Reis, São Vicente e Cananéia onde, pouco mais adiante, Tordesilhas fechava a raia da América Portuguesa. Como se nota, do ponto de vista meramente náutico, o posicionamento de uma feitoria em Cabo Frio seria exeqüível e lógico, e no enfoque 
estratégico, estaria situada na "porta de entrada" para o Brasil meridional, justo - por assim dizer - na primeira marca de aterragem. ${ }^{9}$

\section{3 - O Fortim de Vespucci}

O ano da Graça de 1503 foi um dos mais duros para os portugueses. Não havia trigo e os preços eram tão altos que mesmo aqueles com fortuna sentiam-se afetados pela carência de gêneros. Navios eram despachados para buscar suprimentos nos mercados da Europa e do Norte da África, especialmente grãos.

Não obstante a adversidade - que pouco seria recordada quando se abatesse a tragédia maior, a fome e a peste de 1506 - é mesmo difícil de acreditar que Portugal sustentasse, então, um grande esforço naval com várias frotas de guerra batendo-se em mares diferentes. Atendendo a um pedido do Papa, D. Manoel enviara uma esquadra de trinta navios e 3500 homens de combate, para dar socorro aos venezianos ameaçados pelos turcos. Ao mesmo tempo, preparara descomunal armada contra os mouros do Norte da África, enquanto enviava para as Índias duas frotas com seis navios, os de Afonso e Francisco de Albuquerque. Mas não ficou aí. Destinada ao estreito do Mar Roxo, sob o comando de Antonio Saldanha, havia ainda largado da barra de Lisboa uma flotilha de três naus para fechar a passagem aos navios árabes de Meca.

Nesse momento, é bom recordar, duas outras naus seguiam para Terra Nova em busca de Gaspar e Miguel CorteReal, navegadores desaparecidos naquelas paragens. Com todas estas forças empenhadas em intensas atividades, mesmo assim, em 10 de junho de 1503 suspendiam ferros do lagamar no Tejo, sob o comando de Gonçalo Coelho, seis navios de oceano. Destino: os novos territórios do Atlântico Sul Ocidental, a Terra de Gonçalo Coelho, o próprio capitão-mor, como aparece na carta náutica do italiano Vesconte de Maggiolo, traçada em Gênova 
(1504), legendada com esse título na parte brasileira do mapa. A respeito desta última expedição pouco se sabe por fontes portuguesas, apenas o número de embarcações, o nome do comandante, o porto e data de partida, o retorno com perda de quatro embarcações e a informação sucinta (como sempre) da carga de pau-brasil, macacos (bugiaria) e papagaios.

Amerigo Vespucci não descreve o litoral do Brasil (a partir do Cabo de Santo Agostinho) em qualquer das três cartas onde tratou da expedição ou viagem de 1501 . No relato da viagem de 1503, constante da Lettera (enviada a Soderini), é que se refere à baía de Todos os Santos. É a única descrição da viagem e se encontra publicada no Quarto Viaggio, texto sobre o qual foi realizada a tradução latina das Quatuor Navigationes, obra em latim dedicada ao duque Renato de Lorena.

$\mathrm{Na}$ redação da Lettera insinua Vespucci (ou o suposto Vespucci) que depois de grandes perigos e aventuras, sobressaindo-se os naufrágios com perdas humanas, acabou por descobrir a baía de Todos os Santos e, depois de dois meses nessa região, acompanhado do outro barco da conserva, navegou pelo correr da costa 260 léguas para o sul, até chegar a um porto onde ficou resolvido construir uma fortaleza (fare la forteza). Ali, depois de carregar durante cinco meses pau-brasil, de fazer uma incursão de 40 léguas pelo interior acompanhado de trinta homens, e de construir o fortim - guarnecido o posto com 24 homens, sobreviventes da nau capitânia - como não podiam navegar mais além "por faltar-nos gente e aparelhos" (a causa que non tenauamo genti \& mimancaua molti apparecchi), voltaram os dois navios a Portugal.

Assim, foram deixados os tais 24 tripulantes em terra, com mantimentos para seis meses, 12 bombardas e muitas outras armas. A fortaleza, segundo o futuro Piloto-Mor de Espanha, ficava fora da linha equinocial da parte sul, ou seja, abaixo do Equador, em 18 graus de latitude, e a 37 graus de longitude contados a partir do meridiano de Lisboa. Se for levada em conta apenas a latitude, a fortaleza teria sido erigida em Caravelas, no sul da Bahia (e muito perto de Porto Seguro), isto é, exatamente por trás dos Abrolhos, seus recifes, parcéis, 
obstáculos e perigos o que, evidentemente, não dá para admitir. Mas quando são interpretadas as coordenadas geográficas, latitude e longitude, a "feitoria" de Vespucci vai parar bem perto de Brasília, para os lados de Paracatu, Minas Gerais ( $37^{\circ}$ a oeste de Lisboa).10 Então, como se chegou a "Cabo Frio?"

$\mathrm{Na}$ impossibilidade de serem aceitas as coordenadas, os cálculos voltaram-se para as distâncias lineares registradas na Lettera, ou seja, para a informação de situar-se a feitoria a 260 léguas da baía de Todos os Santos11. Como o navegador espanhol Diego Garcia, em sua Memória, assinala para o trecho entre os cabos de Santo Agostinho e Frio um intervalo de 350 léguas - e como de 100 léguas era a distância habitualmente aceita entre o primeiro e a baía de Todos os Santos - chega-se à conclusão de que a escápula, mesmo considerando o escrito de Vespucci, ficava a 10 léguas depois de Cabo Frio para um navio proveniente da Europa. ${ }^{12}$

Autores do século XIX, engajados numa corrente encomiástica dos trabalhos do navegador, linhagem esta encabeçada por Humboldt e na faixa brasileira por Varnhagen, concluíram por Cabo Frio (muito embora bem distante de Caravelas) devido, sobretudo, ao topônimo contido no Diário da Nau Bretoa. Ora, numa época em que os pilotos e consultores de Cabral (Mestre João, entre estes) chegavam com bastante precisão à verdadeira latitude do Porto Seguro, os escritos atribuídos a Vespucci mostram um cosmógrafo e navegador atrapalhado com a geografia e com os cálculos a respeito de uma região já percorrida (segundo o próprio) em 1501. É difícil de fugir, portanto, de uma das seguintes conclusões: a carta é falsa, no sentido de ter sido manipulada pelos editores ou Vespucci entendia muito pouco, na época, de singraduras e coordenadas geográficas.

O curioso, porém, na lógica da narrativa é terem os capitães, sem gente e equipamentos para navegar, deixado duas dúzias de tripulantes na forteza, com mantimentos para seis meses, e rumado de volta para Portugal. Antes disso, com trinta homens, realizam excursões de 40 léguas para o interior (mais ou menos 320 quilômetros), quebrando o efetivo para guarnecer as 
embarcações, para as obras da feitoria e para o preparo, embarque e estiva do pau-brasil, etc. As inconsistências não param aí. Uma das críticas mais candentes e fundamentadas às cartas, além das enormes contradições entre elas mesmas e dos disparates geográficos, é a do suspeito intento de paralelismos com as viagens de Colón (até no quantitativo), de quem pretendem as missivas elidir a autoria do descobrimento do continente americano ${ }^{13}$, de subtrair seus méritos e os de vários navegadores espanhóis e portugueses, e de suplantar a todos com os seus feitos.

Quando a Lettera arremata a quarta e última viagem de Amerigo, com a construção do fortim das doze bombardas, analogamente, também Colón construíra uma na primeira viagem, à qual deu o nome de Natividad, onde deixou para a guarnição bombardas, pólvora e apetrechos de guerra, conforme as anotações referentes a 26 de dezembro, em seu diário. Coincidência? Na verdade, a maneira mais adequada (ou menos polêmica) de enfocar a questão dos textos atribuídos a Vespucci é a de considerar as cartas como paráfrases ou versões modificadas e "melhoradas" de escritos autênticos, os quais sofreram interpolações, enquistamentos e ajustes no interesse de uma propaganda com propósitos certos, veiculada ao longo de muito tempo.

Do ponto de vista crítico, as cartas preludiam manifestações românticas destinadas à divulgação para um público interessado no exótico e, por isto mesmo, despojadas do rigor probante. Está com a razão o historiador Max Justo Guedes ao lembrar "que o verdadeiro estudo das primeiras expedições tem que ser baseado em fontes mais realistas e menos fantasiosas, sendo as de natureza cartográfica as mais importantes, porquanto foram o registro gráfico, elaborado por especialistas, dos novos conhecimentos." "A coadjuvá-las, dispomos hoje de parca mais capital documentação coeva, especialmente de natureza epistolar, esta última da lavra de agentes ou nautas italianos, participantes das navegações portuguesas". "Finalmente, devem ser utilizadas as informações dos Cronistas e os relatos de Vespúcio, como elementos de 
interligação entre os dados extraídos dos monumentos cartográficos ou das fontes primárias mencionadas". ${ }^{14}$

\section{4 - Flora Utilitária e Toponímia}

Lembrava Roberto Da Mata, na apresentação do livro de Maria Beltrão, "Pré-história do Estado do Rio de Janeiro", que os aspectos essenciais do mundo humano - os planos da cultura, da sociedade e da natureza - encontram-se interligados. No exame da tese de Laguarda Trías, através de um conceito homólogo, buscou-se distinguir os inter-relacionamentos que estariam ali implicados. Além de pistas rastreadas na própria época de instalação da feitoria, seriam susceptíveis de ocorrer sinais que, impregnados naqueles aspectos essenciais do mundo humano, teriam se projetado para o futuro imediato, ainda no século XVI e no século XVII.

Um dos instrumentos normalmente recipiendários de tais efeitos de impregnação é, justamente, a toponímia, um dos mais importantes elementos processualísticos do estudo da cartografia histórica. No trabalho de investigação cabia ajustar o enfoque de pesquisa à natureza dos objetivos de escambo da feitoria: a flora utilitária, o pau-brasil.

O exame da toponímia, mais precisamente, o da toponímia de origem tupi, indica o lado oriental da Guanabara, o lado de Niterói, como o primeiro melhor esquadrinhado pelos portugueses e ao qual dedicavam um interesse muito mais significativo do que à banda ocidental, onde Estácio de Sá, por razões derivadas da ação de Villegagnon, fundou a cidade de S. Sebastião do Rio de Janeiro, em 1565.

Esse "Rio de Janeiro antigo", de antes da década de sessenta, representava uma localidade marítima bem conhecida e freqüentada de longa data pelos barcos portugueses do comércio do $\mathrm{PB}$ e de outros artigos, onde, entre as diversas referências geográficas da ria, destacava-se a ilha do Governador, a ilha do Gato dos índios maracajás. 
A expressão "Ilha do Gato», de seu turno, encerra simbologia particular entre o elenco de geonomásticos. Os signos, num processo de comunicação, não têm caráter meramente arbitrário.

No caso da toponímia lusa da baía de Guanabara - onde a ilha é um dos sítios que registraram nome português (e não tupi) dos mais antigos - a terminologia adotada está contida num desenrolar cronológico vagaroso até 1560, substituída progressivamente à medida que a colonização, melhor dizendo, a agricultura européia, ganha corpo.

Nessa marcha cronológica, o designativo ilha do Gato, símbolo contextual de uma fase de presença lusa bem diferenciada daquela que se inicia com a fundação da cidade no Rio de Janeiro, vai sendo ultrapassado por novas expressões semânticas, conformadas a significações que os lingüistas denominam de situacionais. A progressiva ocupação agrária deixa para trás a antiga designação, substituída por uma que revela ou espelha, a nova situação: Ilha dos Sete Engenhos.

Mais tarde, ainda, com o açambarcamento de propriedades territoriais na ilha pelo Governador e, em seguida, por descendentes seus, um novo símbolo hierarquiza-se na linguagem do povo, transmigrando finalmente para a toponímia oficial: ilha do Governador.

Logicamente ocorrem sincronismos nesses processos de adoção, com as terminologias coexistindo durante um certo tempo, às vezes por mais de uma geração. O nome "Gato", equivalente ao tupi "maracajá" (gato selvagem), que vinha de épocas bem arcaicas, continua a aparecer, adotado para sítios da própria ilha, ou como voz recorrente para designá-la por inteiro, tal a sua impregnação.

Vale acentuar, da consulta a mapas antigos portugueses, que sítios guanabarinos de conhecimento mais recente ou de menor força de evocação do que a Ilha, seguiram batizados com nomes em tupi. Percebe-se, também por aí, o vigor de uma longa tradição, expressa no titulamento daquele território insular com um nome português. 
A geonomástica não só confirma antiga familiaridade portuguesa com a Guanabara, mas faz denotar que neste conhecimento se integra a fisiografia da ilha do Governador e seus arredores. Porém, é quando são examinados os atos notariais à época, ou pouco antes da fundação da cidade do Rio de Janeiro, que se alarga a certeza de que os portugueses distinguiam (bem) e freqüentavam as paragens da Guanabara, especialmente o fundo da ria e toda a sua banda oriental, por tempo longo, o suficiente, para conhecer ou atribuir denominação geonomástica a todos os sítios de um sertão que se costuma imaginar, até ali, desconhecido ou pouco visitado pelos lusos.

Como se sabe, a cidade de S. Sebastião do Rio de Janeiro foi fundada a partir de um arraial paliçado, na entrada da barra de Guanabara, em 1 de Março de 1565. Não obstante, antes dessa data, já existiam residentes e proprietários portugueses na orla da ria, como se depreende dos balizamentos constantes de registos fundiários de São Vicente. O noticiário dos viajantes espanhóis ou daqueles que com eles estavam em arribadas nas costas brasileiras, os despachos diplomáticos castelhanos e a correspondência enviada a Carlos V por Luiz Ramirez, fazem acreditar numa presença européia residente no Rio de Janeiro, em datas arcaicas, que podem recuar, segundo essas fontes, a antes de 1515. Da mesma sorte que na viagem de 1511 da nau Bretoa, tocando numa ilha para abastecer na feitoria, o fundeadouro espanhol de Luiz Ramirez, dezessete anos depois, é também numa ilha - protegida por grande montanha - onde abundava o pau-brasil.

O estudo da topografia histórica reforça a crença num papel importante da Ilha do Gato e seus arredores, como ponto de fixação da feitoria no espaço insular. A avaliação dos sítios da orla ocidental da baía de Guanabara, no século xvi, retrata um litoral marcado pelos brejos e pântanos, e pela deficiência de fontes de água potável em largos trechos dessa faixa do recôncavo, em particular, nas áreas mais próximas da barra. O Rio de Janeiro, por causa da iniciativa francesa e na importância de neutralizarem os portugueses os objetivos de Villegagnon, foi 
erguido na linha do conflito, no lado ocidental, proximidades da boca da Guanabara. Comparada essa parte do recôncavo com determinados sítios da sua geografia, em especial com os da ilha do Governador e arredores, nota-se diferenças bem significativas que definiriam, em tese, esta última como ponto mais susceptível de atração, na recolha de vantagens estratégicas (de natureza militar, econômica e ambiental) para o estabelecimento de uma feitoria no Rio de Janeiro.

\section{5 - Condicionalismos}

O exame dos condicionalismos da exploração do paubrasil, diante do volume de tráfego do lenho enunciado na epistolografia e na diplomática, revela uma série de constatações.15

Assim, se a exploração de pau-brasil reclama a prévia localização da espécie vegetal no intrincado da floresta e envolve um demorado esquema de corte, desbaste, falquejamento, transporte e acumulação na praia, o estabelecimento de feitorias, por sua vez, demonstra a existência de um trânsito constante nas rotas de navegação, pelo necessário revezamento das guarnições de terra e pelo obrigatório ressuprimento de víveres, ferramentas, apetrechos e munições dessas frentes de trabalho.

Se não remanescem dúvidas de que o início do trabalho de feitorias, no Brasil, se dá ao sul da linha dos Abrolhos, e se há notícias de atividade em Porto Seguro, desde muito cedo após a arribada da esquadra cabralina, as anotações de Vespucci, levaram Varnhagen a definir Cabo Frio como a sede escolhida no esquema da sua viagem, em 1503.

As atividades em "Cabo Frio" foram de tal ordem que, secundadas ou não por feitorias posteriores, ao norte da barreira dos Abrolhos, alteraram a toponímia e influenciaram a cartografia de então. Seriam também suficientes para engrossar o intenso tráfego descrito pelo agente comercial florentino em Sevilha, Rondinelli, ou pelo correspondente de Veneza, Cha 
Masser e sustentar os inconformismos castelhanos com o desabusado movimento de $\mathrm{PB}$, de outros reinos, nos portos da Espanha.

Os montantes de madeira tintorial deveriam ser, obrigatoriamente, proporcionais à capacidade de fornecimento da feitoria em questão. Dito de outra maneira, não se pode esquecer que tão volumoso movimento seria, necessariamente, harmônico à capacidade de fornecimento da feitoria, indicando uma estrutura capaz de justificá-lo.

Dessa forma o estudo de localização dessa feitoria levou em conta, primeiro, as condições do sítio como fonte de suprimento do lenho em grande escala16; segundo, os pressupostos assecuratórios das garantias de aportamento, reparo e carenagem das embarcações, de refresco e aguada, e de sustentação das tripulações durante a permanência (a da nau Bretoa foi de cerca de dois meses). Quanto a este último ponto, não poderia, por exemplo, dispensar um forte apoio indígena na produção e fornecimento de farinha de mandioca, tanto para o consumo da equipagem durante a estadia, como para a viagem de regresso.

Estaria, assim, localizada perto ou junto a uma grande aldeia habitada por nativos confiáveis, amigos e dispostos não apenas ao comércio como à proteção dos europeus. Essa aldeia precisaria ser grande, o suficiente, para permitir o moroso trabalho de campo, com as operações de localização, corte, preparo e transporte das toras de madeira; para ajudar no erguimento dos depósitos, na acumulação e faxina do lenho e, com o trabalho de suas mulheres, para colher e preparar toda a mandioca necessária às tripulações.

No Regimento da nau Bretoa estão incorporados indicadores muito importantes a respeito da feitoria do "Cabo Frio" e da sua localização numa ilha. Diante da análise do "Regimento", dos condicionalismos e dos indicadores fisiográficos, não se sustentam as hipóteses de Cabo Frio e Porto Seguro (Jaime Cortesão) como locais do estabelecimento.

Porto Seguro, como sugeriu Jaime Cortesão na trilha do Rio d brasil da carta de Alberto Cantino, seguramente também 
não era. A feitoria encontrava-se numa ilha e Porto Seguro ou a baía Cabrália, estão onde sempre estiveram, em terra firme, no continente. Sob tal enfoque, a ilha do Governador ou ilha do Gato, na baía de Guanabara, apresentava-se como um local de boas possibilidades para abrigar o posto de comércio.

Uma confrontação entre as características ambientais, de hidrografia e de navegação, o exame da capacidade de apoio logístico, e a avaliação da geografia utilitária e das referências estratégicas entre Cabo Frio e o Rio de Janeiro, constituiu um outro método de procura da resposta para o problema da localização da feitoria.

Diante dos quadros de situação traçados por franceses e portugueses nos textos e nas assinalações da cartografia, o posicionamento do Rio de Janeiro é sempre magnificado. Jamais Cabo Frio ganha em qualquer destaque, a não ser em restrições importantes como sítio de ancoragem e passadio. A vulnerabilidade logística de Cabo Frio é manifesta, a começar pela carência de água.

Nem de longe poderia concorrer com o Rio de Janeiro. Possuía, nas margens da lagoa de Araruama, disponibilidades de madeira tintorial e de outros produtos da flora utilitária, de sorte que também ali se faziam escalas para completar a carga. Porém, esbarrava numa limitação bastante importante, que era a falta de água. Este problema sempre perseguiu Cabo Frio e seus moradores e, no século XVI, era particularmente delicado para as embarcações veleiras. Sujeitas a tantas incertezas de rota, as aguadas eram ponto-chave na definição das escalas de abrigo e refresco.

A prova conclusiva da vulnerabilidade de Cabo Frio, em suportar estabelecimentos permanentes, encontra-se na diretriz de Villegagnon, após inspecionar toda a região e optar pelo Rio de Janeiro.

Testemunho cabal é proporcionado pelo franciscano André Thevet, em duas das suas obras. Nas "Singularidades da França Antártica", recolhe-se a sucinta e objetiva informação: "guiados pelo mesmo chefe (Villegagnon), procederam os franceses a um cuidadoso reconhecimento da região do Cabo Frio, chegando à 
conclusão de que não havia nella agua doce senão bem distante. Pelo que ficou resolvido, com pezar geral, que, não obstante a amenidade do clima, era inconveniente o estabelecimento da expedição nesse lugar, ou a permanencia nelle por mais tempon.

De seu turno, o exame comparativo entre as características hidrográficas dos dois sítios marítimos, reforça a vantajosa posição da Guanabara nesse alinhamento da costa. Às diferenças de porte e segurança entre esta e Cabo Frio, juntamse as facilidades de manobra para o acesso ao Rio de Janeiro, muito particularmente, numa época em que os perigos da costa não estavam assinalados em cartas de detalhe, nem os pilotos se arrimavam no socorro alerta dos faróis.

\section{6 - Cartografia Histórica}

Ao atingir as costas do Rio de Janeiro, os franceses não apenas carregavam o PB entre as matérias de valor tintorial e múltiplo uso. Davam carga também de pimenta vermelha ou "pimenta da terra" em quantidade suficientemente expressiva para ser um dos temas do descaminho denunciado por Francisco Porto Carreiro, em carta ao rei de Portugal, datada da Bahia, em 11 de agosto de 1556. Nessa correspondência, porém, num item posterior, alerta para uma notícia que lhe pareceu bem fundada, a de que os franceses estariam construindo um fortim em Cabo Frio, numa pequena ilha dentro da baia.

Entretanto, não era no Cabo Frio propriamente dito a construção francesa, mas, no Rio de Janeiro, com o encrave de Villegagnon e as obras do baluarte do ilhéu Serigipe. Teria sido um lapso de Porto Carreiro ao transmitir a mensagem, ou a expressão Cabo Frio fora usada de forma genérica, como referência ampla de identificação geográfica?

(...) avjso a vossa alteza que tenho por nova serta que os ffrancezes ffazem huã ffortalleza no cabo ffryo numa ilha pequena que esta tjro de berço da terra fyrme demtro... na ... bahya (...) 
A descrição é exatamente a do Forte Coligny, posicionado na distância referida e assentada em um ilhéu. Imediatamente, no parágrafo anterior, a carta mencionava a presença de três naus inimigas no Ryo de Janeiro (dando a aludida carga de madeira tintorial e pimenta), o que chama ainda mais atenção para o emprego de "Cabo Frio", no parágrafo seguinte. Muito embora, na época, Cabo Frio constituísse um determinado sítio na costa, referido como já o havia feito o mesmo Portocarrero em outra missiva, de 1555, o emprego do geonomástico aqui se dava na acepção ampla.17

Ainda em 1555 - 1556, "Cabo Frio" poderia ser tomado como posição geográfica regionalizada e não, forçosamente, como um ponto determinado na costa.

Isto é verdade, na medida em que, muitos anos depois desta carta, nos forais de concessão de sesmarias, empregavam os portugueses a expressão "Cabo Frio" e "para as bandas de Cabo Frio", ao designarem datas de terrenos no litoral fluminense, em regiões abarcadas pela atual Niterói - portanto, no lado oriental da Guanabara - ou na linha da costa, logo após a boca da baia. Tais descrições notariais abrangiam terras muito mais próximas do Rio de Janeiro do que da localidade de Cabo Frio e, como é natural, atendiam a tradições até então vigentes.18

Com isto, Niterói, Piratininga, Maricá, São Gonçalo, Magé (ou Magepe), Macacu, Suruí, Irajá e não esquecer a ilha do Governador, estão compreendidos no "Rio de Janeiro" do século XVI e XVII, para ficar só com estas localidades e nas eras apontadas. De certa forma, Niterói seria "mais" Rio de Janeiro do que o próprio Rio, a levar em conta testemunhos cartográficos e iconográficos.

Sob o ângulo das ilustrações cartográficas, bem parece que o lado oriental - que se costuma chamar de Niterói - teria sido primeiro esquadrinhado do que a banda ocidental, onde Estácio de Sá acabou (por razões derivadas da ação francesa de Villegagnon) por estabelecer a povoação, povoação esta que levou o nome de São Sebastião, de uma localidade marítima já conhecida e bem freqüentada, do Rio de Janeiro. 
O exame das cartas geográficas é bastante elucidativo quanto a este aspecto indiciador. Partindo das elaboradas no começo do século XVII, para as mais antigas, vai se notar uma interessantíssima familiaridade com as posições à nascente, a maioria refletida em nomes tupis, ainda que estropiados.

No Atlas de João Teixeira Albernas o Rio de Janeiro - no talhe de 1624 - do meio da Guanabara para o fundo do recôncavo, recebe um maior número de topônimos a oriente e ao norte, do que a oeste onde a cidade foi erguida. A ilha do Governador, que habitualmente se considera como esse nome pelas extensões de terra de Salvador Correia de Sá, titular daquele cargo, vem batizada de Ilha do G. Martim de Sá, ou seja do Governador Martim de Sá. O número de "construções" assinaladas, sem contar as fortalezas, é maior daqueles lados do que da margem a poente.

O ponto focal da carta, vista como expressão estética, é a mancha gráfica, em cor escura, com o delineamento da cidade do Rio de Janeiro, em frente à ilha das Cobras. Entretanto, as posições geográficas em maior número assinaladas, não correspondem a essa faixa do desenho, mas àquelas já apontadas no lado de "Niterói".

O mapeamento levado a cabo por Jacques de Vau de Claye, durante a expedição francesa capitaneada por Felipe de Strozzi, no reconhecimento do litoral brasileiro, traçou um interessante esboço do que chamou le vrai pourtraict de Genèvre et du Cap Frie. Datado por referência a 1576, tem a descritiva enquadrada pela ótica militar de sua finalidade.

Também essa carta apresenta um número bem maior de marcações a oriente do que a ocidente, com assinalações ao fundo da Baia de Guanabara e na Ilha do Governador. O bloco a oriente caracteriza-se, porém, como um braço de terra em forma trapezoidal, de base larga, integrado intimamente por Niterói e Cabo Frio, um às costas do outro.

Outra carta muito importante é a do português Luiz Teixeira (cerca de 1574) com a estampa da Baia do Rio de Ianeiro e a cidade de S. Sebastiam. Embora equivalente a um portulano, integrado ao Roteiro do todos os sinaes (...) que ha na Costa do 
Brasil (...), contém significativas informações da ocupação das margens da Guanabara, do seu conhecimento e exploração econômica por parte dos lusos e das vias de penetração para o interior, a partir do fundo do recôncavo.

O que aparentemente tem passado despercebido dos examinadores dessa carta é o enlace de informações contidas na face oriental da planta, traduzida na seqüencia de acidentes hidrográficos assinalados e nas legendas compostas à sua margem. Por ali se vê que, em primeiro lugar, o litoral à direita e ao norte do observador foi muito mais palmilhado, conhecido e utilizado até ali pelos portugueses do que a banda onde está erguida a cidade.

Segundo: a cidade de S. Sebastião do Rio de Janeiro, com sua vocação de economia extrativa - conforme as descrições vinculadas à época e ao início de século XVII - não fazia mais do que dar prosseguimento a atividades muito antigas e lucrativas que acabaram por sustentar a escolha pelo povoamento e fortificação daquela área estratégica, sob risco da definitiva ocupação francesa.

Os topônimos se não são de origem portuguesa, e estes são poucos, são tupis, adotados e "oficializados" ao longo de décadas, muito antes, portanto, do erguimento da povoação do Pão de Açúcar ou da transferência da cidade para o morro do Castelo, situada no primeiro terço à esquerda do desenho. Essas designações jamais foram analisadas em relação a seu valor simbólico de natureza econômica, o qual só poderia remanescer se acolhido por tradição das mais pacíficas. Equivale dizer, após décadas de assimilação pelos freqüentadores e pelos estantes naquelas praias.

A não ser a ilha de Villegagnon, assinalada no francesismo Vilaganhão, os termos são todos "aportuguesados", no sentido de que o tupi é grafado por uma fonética de interpretação essencialmente lusa. O mapa consagra a longa faixa do levante como fonte supridora de essências de tinturaria, e é notável a presença de $\mathrm{PB}$, afirmada e reafirmada na carta da baía.

Claramente está registrado, pouco acima do terço médio do desenho e à direita: aqui ha pao vermelho. Significaria a 
existência de lenho naquela enseada? Não iria assinalar o cartógrafo aqui ha, quando não mais existisse sequer lembrança da espécie (no caso da extração da madeira ter começado muitos anos antes) e se limitasse, apenas, àquele ponto. A informação é de conteúdo amplo e geral.

As confirmações diretas e indiretas da disseminação de fontes de corantes vegetais, em toda aquela vasta área, são patentes. Poucos se deram conta de que o nome do rio Macacu (maçucu, assinalado a nordeste no fundo da baia) significa, exatamente, "árvore tintória".

Um outro ponto assinalado é o recorte de certo curso d'água, mais ao sul e em frente à cidade nova de S. Sebastião, referido como rio Ubiraém, R. ubiraem. Ubiraém ou buranhém é uma árvore da família das sapotáceas (Pradosia lactescens). Significa "pau doce" ou "casca doce", de onde se tira substância adstringente e matéria corante.19

Niterói e, por força do termo, a faixa oriental da Guanabara, é uma vez mais posta em evidência, com o relato de Hans Staden. Narrando suas desditas nas mãos dos tupinambás, conta o artilheiro da frota de Sanabria:

Cerca de oito dias antes do início da expedição guerreira (dos índios que o haviam aprisionado) chegou um navio francês em um porto, que dista oito milhas (milhas alemãs de $7.420 \mathrm{~m}$ )) de Ubatuba, ao qual os portugueses chamam Rio de Janeiro, e os índios, Niterói. Aí costumam os franceses fazer carregamento de pau-brasil.20

Mas só os franceses freqüentavam em 1554 aquelas águas abrigadas de Niterói?

É o próprio Staden que esclarece.

Nisso, veiu uma manhã, quando ainda estávamos no porto do Rio de Janeiro, um pequeno navio portugues e quís partir da baía. Havia comerciado com os maracajás, uma tribu de índios que tem amizade com os portugueses e cuja região se limita com a terra dos tupiniquins (aqui o autor trocou "tupinambás" por "tupiniquins"), os amigos dos franceses.21 
Continuando a narrativa, Hans esclarece que o barco português era de Pedro Roesel, o feitor alemão dos Schetz em São Vicente.

Em 1553, Ulrico Schimidel viu ancorado em São Vicente um navio português carregado de algodão, açúcar e pau-brasil, pertencente a João von Hielst, agente da casa Erasmos Schetz (de Antuérpia), em Lisboa. O factor ou encarregado, em São Vicente era Peter ou Pedro Roesel, gerenciador dos negócios do engenho de açúcar "São Jorge dos Erasmos", do qual provinham os suprimentos dessa mercadoria embarcados no navio. Ora, Roesel era, também, o proprietário do pequeno navio que, em 1554, após os contatos habituais de comércio com os índios maracajás, na ilha do Governador ou do Gato, foi atacado fora da barra pela nau francesa Catherine de Vattaville onde se encontrava, de regresso à Europa, Hans Staden. Roesel e sua pequena tripulação conseguiram repelir os franceses e causar bastante estrago com muitas baixas, entre mortos e feridos, na equipagem dos atacantes.

Assim, como é sabido que na Capitania de São Vicente não havia $\mathrm{PB}$, não é difícil de se chegar à conclusão de onde provinham os embarques do lenho tintorial.22

Não havia pau-brasil no litoral norte de São Paulo ou nas ilhas adjacentes (Cananéia, etc.), faltando também abaixo do Rio de Janeiro, o que inclui a ilha Grande e arredores.23 Dessa forma, a ilha do Governador e as que lhe são adjacentes (ou o litoral circundante), e os indígenas temiminós, também chamados maracajás, surgem, claramente, como supridores dos embarques de matéria corante, o que fica subtendido em Lery (1557) e confirmado em Gabriel Soares de Souza24 e em Hans Staden.

Este último produz interessante informação ao juntar uma xilogravura ilustrativa do episódio Roesel. O desenho, cerrado nos quatro cantos por bordaduras, mostra um braço de mar fechado em todo o lado esquerdo e na parte superior. Esse mar está limitado por outro trecho de terra no ângulo inferior direito.

No mar combate um navio de dois mastros, com a bandeira das quinas no topo, assediado por dois bergantins e várias 
canoas índias. A proa do barco português está voltada para a abertura de mar acima do desenho, como se ali fosse uma boca de barra. Alheia aos acontecimentos, aparece na gravura uma nau de três mastros carregando toros de madeira, ou seja, paubrasil. O desenho alude a uma aldeia de índios maracajás, abaixo da qual encontram-se os nativos que realizam a estiva dos paus e, no alto, uma outra aldeia, a dos tupinambás.

Convém notar o que muitos autores ainda não o fizeram: a ilha era um ponto tão importante de presença antiga e de permanência temiminó que, não importando o lado ou partido do cartógrafo ou do cronista, a designação era obrigatória e assentava-se no indiscutível respeito ao nome de seus originais e combativos ocupantes: os maracajás.

Essa presença maracajá, por outro lado, identificava-se com um ambiente de tal sorte familiar aos portugueses, que o batizaram como uma ilha "portuguesa", no nome português de ilha do Gato.25

\section{7 - Peabirus, os Caminhos Antigos}

O triângulo geográfico formado pela ilha do Governador e o recortado litoral fronteiro, desde Inhaúma a Irajá, constituíam região integrada a outros importantes fatores evidenciados durante a investigação. Entre esses fatores estratégicos estão os peabirus, os caminhos antigos usados pelos caçadores do Pleistoceno e aproveitados pelos índios.

Quase invariavelmente, historiadores e pesquisadores da cartografia territorial, ao examinarem a temática dos peabirus caminhos ligando pontos da costa brasileira e esta, pelo sertão afora, com o mais distante interior - prendem-se a uma origem indígena das estreitas sendas. Os peabirus, no entanto, são muito mais antigos. ${ }^{26}$ 
Quando se avalia a dificuldade de penetração pelo intrincado da Mata Atlântica é que se pode entender o significado das trilhas.

As evocações aos peabirus são constantes, mas indiretas. Embora implicitamente referidas na bibliografia histórica dos primeiros tempos, passam desapercebidas à boa parte dos leitores (e, por vezes, aos próprios pesquisadores) não afeitos aos condicionalismos fisiográficos e, portanto, às limitações de ingresso e passagem pela floresta meridional brasileira.

Jaime Cortesão, ao narrar a extraordinária aventura do náufrago Aleixo Garcia, tripulante português da armada espanhola de Solis - o qual, a partir de Santa Catarina e largando do Paraná à frente de dois mil guaranis, foi atingir os redutos incas, antes de Pizarro, cerca do ano de 1522 - pergunta: "Como explicar a profundíssima penetração de Aleixo Garcia, num continente, cujo interior era totalmente desconhecido?" 27

Não fosse a existência dos peabirus, a penetração pelo intrincado do jangal atlântico brasileiro seria tremendamente difícil, exigindo sacrifícios ainda maiores do que estes viajantes tiveram que enfrentar, mesmo adotando as trilhas primitivas.

Vencer a Mata Atlântica era disputar com um sistema florestal que se iniciava nas praias, onde a vegetação de plantas herbáceas e arbustivas, cenário ameno e ainda não enunciador das dificuldades escondidas adiante, desenhava agradavelmente o contorno de boa parte dos litorais.

Todos os tipos de acidentes geográficos encontram-se associados à Mata que, em certos pontos, se debruça até bem junto ao mar, sem transições. ${ }^{28}$ Espessa, emaranhada, a mata não permite um fácil ingresso na sua complexa diversidade. Diferentemente da floresta amazônica, muito mais acessível à penetração, a da costa é entrelaçada e vai assim território dentro. O importante e pouco conhecido papel dos peabirus na conquista, em primeiro lugar, da linha da costa até às serranias e, depois, interior adentro, deixa, por vezes, rastos indeléveis na toponímia e na cartografia quinhentista. 
A carta do Brasil, de Lopo Homem (1519), constante do chamado Atlas Miller, é uma peça de rara beleza, recoberta de iluminuras de refinado talhe e de elaborado gosto. Importante como documento cartográfico tanto como artístico, registra abundante nomenclatura de esclarecimento da costa brasileira, excedendo nestas informações qualquer outra carta da primeira metade do século XVI, para semelhante espaço litorâneo.

No mapeamento correspondente à faixa do Rio de Janeiro, consta, entre as duas baías definidoras do território carioca, a de Guanabara - por sinal muito bem traçada em sua composição e delineamento geográficos - e a de Sepetiba, o geonomástico mamgues, fruto, provável, da presença branca naquele trecho. A indicação toponímica está referida a uma zona percorrida por um importante peabiru, o chamado "caminho de Guaratiba", através do qual transitavam os índios entre os dois grandes recôncavos.

Inhaúma é um ponto de especial importância no estudo das trilhas, pois ali se entroncavam linhas, a de Guaratiba com a da passagem da serra do Mar que, depois de ultrapassar o rio Paraíba do Sul, prosseguia para o norte na direção de Minas e alhures. A ilha do Governador ou do Gato, separada de Inhaúma por estreito braço de mar, ostentava rede própria de caminhos a cobrir, como um espinhaço, toda a sua extensão. ${ }^{29}$

Quando Martim Afonso de Souza aporta na Guanabara, em 1531, manda quatro homens em longa expedição por serras e campos, da qual voltam acompanhados, dois meses depois, de um importante cacique das tribos do interior. Isto permite a certeza da utilização de peabirus pelos expedicionários, sem o que não teriam percorrido "terra a dentro", em sessenta dias, 115 léguas na acidentada orografia do Sudeste (aproximadamente $1800 \mathrm{~km}$, ida-e-volta).

Além disso, é particularmente significativa a composição dos suprimentos embarcados na escala do Rio de Janeiro pela esquadrilha de Martim Afonso de Souza, quando se alude a gêneros extravagantes à natureza autóctone, denotando conformidade com uma presença européia residente e com o 
amanho da terra, o que significa, por si só, mais um outro forte indício da localização original da primitiva feitoria portuguesa. ${ }^{30}$

Em fins de dezembro de 1552 ou começo do ano seguinte, a armada de Tomé de Souza fundeou na baía de Guanabara. Nessa época, o antagonismo aos portugueses definia a postura de uma parte do gentio, os tamoios, e a afinidade reinante com os maracajás. A acolhida na ilha do Governador é descrita pelo padre Manoel da Nóbrega, que a denomina de Paranapacu, dando conta dos atos piedosos de pregação e catequese, do total acesso aos maracajás e da franca receptividade do cacique, Maracajaaçu, aos costumes cristãos.

Dentro desse enfoque, há condições documentais para admitir, francamente, a existência de uma zona de influência portuguesa na baía de Guanabara, de tal sorte favorável aos propósitos lusos que, Tomé de Souza, "no início de 1550 determina que não se corte nem se faça carregar pau-brasil, sem os interessados disporem de uma autorização régia", com o embarque do lenho limitado à região dos Potiguares e ao Rio de Janeiro. "Desta sorte, a região do Rio de Janeiro não seria mais considerada como um local deserto e à inteira mercê dos franceses", consoante a observação de Joaquim Veríssimo Serrão. ${ }^{31}$.

A duração da arribada de Martim Afonso de Souza, na Guanabara, em 1531, condicionou a do deslocamento dos expedicionários pelo sertão, e a certeza da adequabilidade do prazo para retorno, como o fizeram, trazendo com eles o chefe indígena. ${ }^{32}$ Por outro lado, convém insistir, a certeza da utilização de peabirus, pelos quatro expedicionários enviados do Rio de Janeiro ao sertão por Martim Afonso - sem o que não teriam percorrido a acidentada orografia da viagem em sessenta dias - implica, no mínimo, o conhecimento e o reconhecimento da Ilha do Governador, ponto-chave no acesso às trilhas, o que confirma um domínio muito preciso da geografia guanabarina. Em outras palavras, a ação desenvolvida pelos quatro expedicionários também demonstra um confiante e desembaraçado conhecimento português da natureza, do ambiente e do apoio disponível no Rio de Janeiro. 


\section{8 - Governador, a Ilha do Gato}

A ilha do Governador apresentava, no século XVI, três características ambientais: era extensa e florestada, era fértil e nela abundavam as fontes d'água. ${ }^{33}$ Ao contrário da várzea do Rio de Janeiro e do arraial de Estácio de Sá, além de não faltar água potável à mão, as suas inúmeras colinas arredondadas não escondiam alagados e pântanos. ${ }^{34}$

Tais constatações reforçam a prova indireta da existência de pau-brasil nas florestas da ilha do Gato, e engrossam o elenco de evidências indiciadoras de ter sido ali a feitoria insular na nau Bretoa, ou seja, a feitoria de 1511 e de antes dessa época.

A prova direta, corolário do processo probatório, reside nas constatações arqueológicas. As pesquisas levadas a cabo no Rio de Janeiro por instituições brasileiras públicas e privadas e estrangeiras, desenvolveram intensos programas de estudos que subsidiaram evidências indiscutíveis de presença portuguesa muito cedo, no dealbar do século XVI, na ilha do Gato.35 E aqui estão presentes sinais proto-históricos evocadores da feitoria.

Os testemunhos arqueológicos dão conta da particular demanda indígena pela ilha do Gato,36 como ponto de fixação de sedes tribais (e não de acampamentos), o que salienta a importância do espaço insulano como referencial para a ocupação estratégica, desde os tempos da pré-história e da proto-história brasileiras.

Muito embora os objetos da cultura tupi (e a maracajá aí incluída) fossem constituídos, na sua maior parte, de matéria degradável, os vestígios de fogueiras, os artefatos de adorno em osso ou minerais e, principalmente, a cerâmica e os artefatos líticos e conchíferos, são os remanescentes elementos informativos dos achados arqueológicos. A cerâmica, pelas inconfundíveis características com que se reveste, "permite o fácil reconhecimento de uma ocupação tupi-guarani», de sorte que essa mesma cerâmica, de confecção e aparência inconfundíveis, "serve de 'peça-guia' para a identificação do grupo". 
O emprego das modernas técnicas de datação, aliadas ao trabalho de escavação, exame, seleção e classificação dos materiais recolhidos, e à análise do partido adotado na disposição do sítio, indicam não apenas a intrusão de elementos da cultura branca, quando ocorrem no cenário indígena, como determina, pela idade, quem seriam tais europeus.

Quando se confronta as datações dos estudos arqueológicos da ilha do Governador e de outros pontos do Rio de Janeiro, com a documentação francesa sobre viagens ao Brasil, com as modernas pesquisas historiográficas e com a cartografia, fica absolutamente claro a quem poderiam ser atribuídos, a não ser aos portugueses, os elementos de cultura européia encontrados nas aldeias tupis da Guanabara e correspondentes ao início do século XVI.

A investigação em detalhe proporcionada por Bonnichon ${ }^{37}$ sobre as atividades franco-brasileiras, mostra que após os eventuais e preliminares contatos de 1504 de um Goneville (se é que ocorreram e mesmo assim, longe da Guanabara), só em 1526 com o impulso dos Verrazano, os franceses debruçam os seus interesses comerciais na costa brasileira, com uma vintena de navios entre 1526 e 1531, navegando provavelmente pela costa nordeste e costa baiana. ${ }^{38}$

Por outro lado, a presença lusa no Rio de Janeiro, antes de 1535, mostra-se indiscutivelmente evidenciada na cartografia, na documentação histórica e na historiografia, para demandar maiores comentários.

As pesquisas arqueológicas levadas a cabo na ilha do Governador, por Maria Beltrão, identificam claramente a aldeia da Estação de Rádio da Marinha (GB-19), na área da ponta do Matoso, como do "período correspondente ao primeiro contato com os europeus", datando o place numa faixa de tempo situada entre 1300 d.C. e 1500 d.C.

«Nas camadas superficiais do sítio a cerâmica indígena aparece associada à cerâmica neo-brasileira colonial e de Macau (ao todo 875 cacos), não se podendo diagnosticar, pela análise 
estratigráfica, se a cerâmica neobrasileira foi um elemento cultural intrusivo ou se processos aculturativos desenvolveram-se entre o indígena e o europeu" (...). "A cerâmica colonial caracteriza-se por fragmentos de utensílios feitos no torno, tais como: vasilhames, cachimbos, etc. Registramos, como elementos da cultura colonial fragmentos de porcelana européia, grandes formões e pregos metálicos, tijolos, etc... ${ }^{39}$

Na aldeia ou aldeamento das Pixunas, GB-18, foi encontrado material europeu associado ao material nativo desde a base do sítio. O assentamento apresentava-se sob uma forma retangular sugerindo, portanto, a influência européia na adoção de modelos de defesa o que também parece refletido, como salientou a mesma pesquisadora, nas aldeias dos tupis reproduzidas no mapa de Vau de Claye.

As escavações na elevação da Escola São Tomé, exibiram restos de um antigo acampamento da cultura tupi-guarani, configurado através de abundante material cerâmico associado à louça de origem européia.

A datação justou a época do sítio ao período histórico, posterior a 1500 d.C.

Conhecendo-se as faixas de datação destes sítios, superpostos a tempos de presença portuguesa comprovada direta ou indiretamente - seja através do testemunho textual, seja através dos indícios claros dessa presença - mas nem sempre referidos a períodos de conhecida presença francesa, torna-se duvidoso admitir, diante também da natureza e origem de certos materiais europeus encontrados (a louça de Macau, por exemplo) que essa influência, essa participação, seja outra que não a portuguesa. ${ }^{40}$

Entretanto, nos testemunhos arqueológicos datados de 1500 e deste ano ao meio da centúria, surgem novos elementos de reforço a uma presença portuguesa das mais arcaicas, constatação a qual, em concurso com todas as demais pinçadas e discutidas no presente trabalho, mostram a Guanabara como polo de estabelecimento português, na mesma época da 
primeira feitoria, da mesma feitoria da nau Bretoa, que era - não se pode esquecer - numa ilha.

O mais peculiar e intrigante, é que o encontro dos restos de "louça de Macau» não houvesse disparado um sinal de alerta entre os historiadores (e entre os pesquisadores da antropologia cultural), diante da datação do achado arqueológico, singularíssimo. Passados mais de trinta anos das descobertas na ilha do Governador e sendo as datações originadas de fonte conceituadíssima e jamais contestada, cabe analisar as implicações, do ponto de vista histórico, daqueles importantes achados, não sem antes avaliar os significados implícitos no espaço, no contexto cultural dos Quinhentos e no tempo do próprio achamento. ${ }^{41}$

\section{9 - Os Achados Arqueológicos e suas Implicações}

A presença da louça de Macau é algo de importância invulgar, diante do significado volutuário do objeto - de onde se originaram os fragmentos de porcelana - e da época de datação do achado.

"Louça de Macau" é uma expressão que alcançou no Brasil ampla disseminação, muito em particular no século XIX, para indicar os produtos da cerâmica chinesa importados nos navios portugueses. Os acontecimentos na Europa, levando o Rio de Janeiro a se tornar a Metrópole, fizeram dirigir às praças brasileiras o fluxo de mercadorias do comércio português com as terras do Extremo Oriente. Na lembrança de Brancante, "quando Cantão, Nankin e Macau passaram a constituir os grandes entrepostos diretos de embarque de louça chinesa; é muito comum chamar-se louça de Cantão, de Nankin ou louça de Macau, a um determinado tipo de porcelana, sobretudo a branca e azul".

Certamente, na época das navegações pioneiras, o século XVI, o produto originário da China ainda era conhecido como "louça da Índia", em decorrência de ser trazido nos navios da Carreira da Índia, abastecedores dos mercados do Ocidente. 
Além disso, nesta fase inicial, não apenas a Índia era a parte mais conhecida do Oriente, como funcionava como entreposto para reembarque das mercadorias recebidas da China.

A terminologia dessa época, por outro lado, aplicava indiscriminadamente as palavras "porcelana" e "louça" em sinonímia, para designar qualquer produto cerâmico proveniente da China, quer se tratasse de uma valiosa peça decorativa Ming ou de um exemplar mais comum. Essa louça "comum", por suas características inimitáveis de qualidade intrínseca e de apresentação, era muito mais cara do que a cerâmica européia a qual, desde há muito, com ela não podia rivalizar.

Reputadíssima e cara, a porcelana que os europeus ainda não sabiam confeccionar, chegava ao Ocidente, ao final do século XV e início do XVI, através dos trâmites de um comércio intermitente e moroso. Vasco da Gama, ao retorno da epopéia do "Caminho Marítimo para as Índias", embarca porcelanas chinesas, as quais não as deixa de mencionar D. Manoel em sua comunicação do grande feito naval, na carta enviada ao Papa em 28 de agosto de 1499. Logo as porcelanas passam a formar entre os itens importantes das cargas das frotas da Carreira da Índia.

Os restos de louça de Macau da ilha do Governador (e nem importa em que quantidade foram encontrados), constituem um fenômeno quase inexplicável. Não "deveriam» estar ali, mas estavam. Haverá, pois uma explicação para o achado e uma interpretação de seu significado. Cabe ao historiador encontrálas e consistentes.

Admitindo que o conceito de datação não é rígido, a assinalação 1500 d.C. corresponde, como refere a própria autora das escavações, ao período do primeiro contato com os europeus. Mesmo ampliando a faixa de tempo para os dez ou vinte anos imediatamente subseqüentes ao ano da Graça de 1500, o emprego de porcelana por homens brancos, na costa sudeste brasileira, continua sendo algo intrigante.

Pelos altos custos e pela fragilidade do objeto e, por outro lado, pela inexistência nesse litoral de comunidades européias coloniais, consoante a historiografia tradicional, não haveria 
como justificar o internamento, no espaço insular, de tão especial e refinado produto. Louça fina e, menos ainda, a trafegada pela Carreira da Índia, não fazia parte dos serviços de naus e caravelas no começo dos Quinhentos. Gamelas de lenho, pratos e copos de estanho, panelas de ferro e objetos cerâmicos que não admitissem sucedâneos metálicos, além dos frascos de vidro grosso e recipientes de madeira, eram em linhas gerais, os artefatos de bordo admitidos junto à matalotagem. De seu turno, ao que se sabe, os barcos lusos não passavam pelo Brasil, mormente no primeiro terço do século XIV, com cargas de artigos orientais. Nem havia porque.

Parece claro que não se pretende vislumbrar aqui a hipótese de tais suprimentos de louça traduzirem o resultado de escalas de navios da Carreira da Índia no Rio de Janeiro, com a carga de torna-viagem. A porcelana chegou às mãos dos nativos ao longo de um processo interativo, com o homem branco instalado nas proximidades dos sítios onde se erguiam as malocas (e, até mesmo, dentro delas, como parecem indicar os estudos sobre alguns desses jazimentos). Essa louça, por motivos óbvios, não entraria na posse dos índios íntegra, ou em sua forma original, mas já em cacos, depois de danificada no manuseio utilitário do homem branco. Vale lembrar que os restos de louça foram encontrados nas escavações de "fossas culinárias", isto é, fossas de rejeitos, concavidades, valas abertas no chão para receber detritos de cozinha ou detritos domésticos da aldeia.

Qual seria o interesse do índio em possuir cacos de louça e depois jogá-los na vala dos rejeitos ? É possível que, em um primeiro momento, o caco de louça tenha sido ofertado ao tupi da mesma forma como os portugueses da frota cabralina 0 fizeram com folhas de papel, objeto extraordinário que empolgou o nativo de imediato. Não havia para este qualquer aplicação prática para o papel.

Já de posse de alguns fragmentos de louça, o índio deve ter encontrado, no decurso do cotidiano da maloca, uma finalidade utilitária para o objeto. Dado que nessas mesmas escavações surgem novos padrões decorativos em parte da 
cerâmica tupi recolhida, onde a superfície dos artefatos mostrase bem alisada, constata-se portanto uma inovação de natureza instrumental no trabalho de acabamento.

Um novo "instrumento" havia caído nas mãos do oleiro, isto é, o ceramista maracajá criara ou encontrara uma nova ferramenta de trabalho. Ao que parece, essa "nova ferramenta" poderia ser o caco de louça da Índia ou louça de Macau. Os bordos de face lisa, vítrea por assim dizer, permitiriam dar ao alisado da massa o acabamento inovador discernido na cerâmica tupi da ponta do Matoso.

Em síntese: os sítios arqueológicos da ilha traduzem importantes revelações proto-históricas quanto aos assentamentos indígenas. $\mathrm{O}$ da ponta do Matoso, da fase cronológica do Descobrimento do Brasil, mostra algo ainda mais importante, para a época, do que um simples aldeamento. ${ }^{42}$

Este sítio permite deduzir - pelos materiais exclusivos ali encontrados - atividades de carpintaria naval, sugerindo carenagem de embarcações, tanoaria, aparelhamentos; enfim, serviços de apoio típicos de uma feitoria, a feitoria da ilha do Gato.

FERNANDES, FERNANDO LOURENÇO. The Portuguese Settlement in Rio de Janeiro. História, v.27, n.1, p.155-194, 2008.

Abstract: The article approaches the investigation about the place where the first Portuguese settlement in Brazil was erected, the first nucleus of European civilization south of the equator in the western Atlantic region. Discussing the theses about the settlement named "Cabo Frio" (Varhagen and Laguarda Trias), the text examines the list of geologic, ethnologic, iconographic, and cartographic factors implied, in light of the elements of historical and archeological proof, to sustain the position of the settlement on Gato Island, the Governador's Island in Guanabara Bay. Evidence of a probable pre-discovery of Brazil prowls the essay with the reinterpretation of the nebulous circumstances that involve the socalled "cycle of brazilwood".

Keywords: Portuguese Settlement; Varhagen; Laguarda Trias. 


\section{NOTAS}

1 Bernardino José de Souza, O Pau-brasil na História Nacional, Cia. Editora Nacional, São Paulo, 1938. Terra da ibirapitanga, Imprensa Nacional, Rio de Janeiro, 1939, de A.L. Pereira Ferraz; e Este nome: Brazil, Agência-Geral do Ultramar, Lisboa, 1967, obra de Adelino J. da Silva Azevedo.

2 Cfr. História Naval Brasileira (HNB), Ministério da Marinha, SDGM, Rio de Janeiro, v. 1. t. 1.

3 HNB, v. 1, t. 1, pp. 254 a 257.

4 Luis Adão da Fonseca, Os Descobrimentos e a formação do oceano Atlântico, Século XIV - Século XVI, Comissão Nacional para as Comemorações dos Descobrimentos Portugueses, Lisboa, 1999, p. 102.

5 Ver José Manuel Malhão Pereira, A Navegação à vela e o condicionalismo físico dos oceanos Atlântico e Índico, in A Viagem de Vasco da Gama à Índia, 1497 - 1499 (daqui para frente denominada pela sigla AVVG), Academia de Marinha, Lisboa, p. 29.

6 António Cardoso, Bartolomeu Dias e o Descobrimento do Brasil, consoante a citação de Jorge Couto, A Construção do Brasil, Edições Cosmos, Lisboa, 1995, p. 378.

7 José Manuel Malhão Pereira, A Navegação à vela e o condicionalismo físico dos oceanos Atlântico e Índico, in AVVG, p. 31.

8 Obra citada, p. 103.

9 Sobre a aterragem, ver Max Justo Guedes, HNB, v.l, t. 1, p. 132.

10 A barra de Lisboa ou barra do Tejo, localiza-se em $9^{\circ} 20^{\prime} \mathrm{W}$, donde o acréscimo de $37^{\circ}$ fornece a posição de $46^{\circ} 20^{\prime} \mathrm{W}$.

11 Entre outros historiadores credenciados, Max Justo Guedes tem mostrado que as distâncias adotadas pelo florentino estão normalmente superavaliadas, com erro de $40 \%$ para mais. Assim, as "260 léguas", se consideradas acriticamente levariam o fortim para as bandas da ilha de São Sebastião no litoral de São Paulo; se dado o devido desconto, o estabelecimento português teria sido erguido em Vitória (por sinal, também uma ilha), no Espírito Santo. Cfr. um dos livros mais recentes deste importante autor, O Descobrimento do Brasil [1500-1548]. CTT, Lisboa, 2000, pp. 43, 57 e 58.

12 Laguarda Trias assinala que, tanto para Vespucci como para Alonso de Santa Cruz (Islario), a feitoria se encontrava próxima ao Cabo Frio, embora este último - segundo o historiador uruguaio - apontasse o fortim situado a 10 léguas "antes del Cabo que diximos llamarse Frio". Cfr. História Naval Brasileira (HNB), Ministério da Marinha, SDGM, Rio de Janeiro, v. 1, t. 1, p. 254. A esse propósito, o Islario general de todas 
las islas del mundo, ( edição [por vez primera], impressa em Madrid, 1918, com prólogo de António Blázquez) informa que depois dos Baixos dos Pargos (na direção Sul) y antes del cabo que diximos llamarse Frio, sale un rio a la mar muy grande y antes de su salida haze uma gran baya de mas de diez leguas de largo, y mas de quatro de ancho (...); junto a esta baya fue donde Amerigo Vespucho (...) fundo una casa donde dexo veynte e quatro cristianos, etc., descrição que levaria o fortim a estar situado na Baía de Salvador, ou seja, na grande reentrância de Macaé (onde, aliás, existia pau-brasil) terra senhoreada, porém, pelos terríveis e imbatíveis índios da estirpe goitacá. Tratavase de uma "zona de exclusão" que brancos e tupis evitavam. Vale recordar o acontecido com a capitania de Pero de Góes, pouco mais tarde.

13 Cfr. Consuelo Varela, obra citada, p. 51.

14 Max Justo Guedes, in Expedições portuguesas e o reconhecimento do litoral brasileiro, HNB, v. 1, t. 1, p. 223.

15 Cfr. a comunicação de Fernando Lourenço Fernandes, Pau-Brasil e o Atlântico Sul; condicionalismos da flora como indicadores de navegações portuguesas ignotas, in Limites do mar e da terra, Actas da VIII Reunião Internacional de História da Náutica e da Hidrografia, Patrimonia, Cascais, 1998 (Ars Náutica). Ver também, do mesmo autor, O Pau-Brasil e o Descobrimento, in A Viagem de Pedro Álvares Cabral e o Descobrimento do Brasil (coordenador Max Justo Guedes), Academia de Marinha, Lisboa, 2003. pp. 229 a 241.

16 O que desde logo, deixaria de fora a localização atribuída por John L. Vogt a Alonso de Santa Cruz, ao imaginar a feitoria na ilha de S.Vicente, litoral de São Paulo ("the Vespucci's feitoria") e onde não havia pau-brasil, como sítio de um entreposto para o comércio da madeira de tinturaria. Cfr. Portuguese exploration in Brazil and the feitoria system, 1500-1530.Dissertação ao Ph.D, na Universidade de Virginia, EE.UU., 1967, p. 138.

17 Cfr. História da colonização portuguesa do Brasil (HCPB), L. Nacional, Porto, 1921-1924, v. III, p.377.

18 Os mapas franceses de Nicholas Vallard (Carta 11, Atlas da The Huntington Library, San Marino, Califórnia) e do abade Desceliers (Carta do Brasil [Amerique ou bresill], planisfério de 1550, British Library, Londres), consagram a designação da chamada "costa LesteOeste" fluminense, exatamente como Cap de frie, logo abaixo do Trópico do Capricórnio. Note-se, sem esquecer de assinalar separadamente o promontório, o que comprova o binômio cartográfico. 
19 Coincidentemente, o rio de Porto Seguro, no Estado da Bahia, onde se cortou e por onde fluiu copiosa produção de pau-brasil nos séculos XVI a XVIII, tem (e já tinha na época) o mesmo nome indígena de Buranhém.

20 Cfr. Duas viagens ao Brasil, tradução de Guiomar de Carvalho Franco, Editora da Universidade de São Paulo e Livraria Itatiaia Editora, Belo Horizonte. 1974, p. 122.

21 Idem, pp. 143 e 144.

22 A cartografia do início do século XVI balizava os pontos da costa onde existia PB. Eram os denominados "rios do extremo", para os quais Laguarda Trias oferece uma apreciação bem sumariada no seu texto (in HNB, v. 1, t. 1, pp. 251 e 252). Citando Alonso de Santa Cruz no Islario e Eugênio de Castro, nos comentários ao Diário da navegação de Pero Lopes de Souza, salienta a falta de pau-brasil na Ilha Grande e na "baya de los Reyes", zona do limite meridional de presença do lenho, consoante a carta de Lopo Homem-Reineis (1519), o "rio do extremo" que aparece também nos mapas espanhóis de Salviatti, Castiglioni (o planisfério de Diogo Ribeiro, de 1525), nos de Ribeiro (1527 e 1529) e no de Alonso de Chaves, Quatri partitu, c. 1538.0 limite meridional de distribuição da essência corante é confirmado por Gandavo.

23 Haroldo Cavalcante de Lima, na publicação Viagem à terra do paubrasil, trabalho escrito com a participação de Marcio Werneck da Cunha, relaciona entre as áreas onde teriam sido constatadas ocorrências de populações remanescentes de Caesalpinia echinata, um indeterminado local na Ilha Bela (Ilha de São Sebastião, litoral de são Paulo). Entretanto, o botânico ressalva que esse registro ainda não foi confirmado através do exame de coleções botânicas. Agência Brasileira de Cultura, Rio de Janeiro, 1992, p. 35.

24 Cfr. Tratado descriptivo do Brasil em 1587, Companhia Editora Nacional, 1938 (comentários por Francisco Adolpho de Varnhagen), 3a. edição, p. 38.

25 A escolha de ilhas para a sede de feitorias, aguadas e portos salvaguardados, era bastante comum na trajetória de conquista portuguesa dos mares. Basta lembrar, na costa brasileira, as ilhas de Itamaracá, em Pernambuco; Santana, no Rio de Janeiro; São Vicente e Santo Amaro, em São Paulo; Vitória, no Espírito Santo, Santa Catarina, etc.

26 De traçado irregular e tortuoso, muitas dessas trilhas situavam-se mais ou menos encobertas pelo mato, disfarçadas por um 
franqueamento nem sempre constante. Não se deve imaginar, porém, que o peabiru - ainda existem sinais remanescentes destas vias primitivas - seja algo mais do que uma senda, uma vereda. A importância dessas trilhas, deve ser associada ao delineamento da piaçaba, o caminho principal que levava, nas malocas ou aldeias da costa, o morador até à beira do mar.

27 A Fundação de São Paulo, capital geográfica do Brasil, Livros de Portugal, Rio de Janeiro, 1955, p. 34.

28 Enquanto as mais importantes florestas européias registam a presença média de 10 espécies vegetais superiores por hectare - e aí podem ser catalogadas a Floresta Negra e a das Ardenas - na Mata Atlântica esses valores ascendem a 600 espécies em área idêntica, consoante o que ocorre nas selvas tropicais.

29 Cfr. Cybelle de Ipanema, História da Ilha do Governador. Livraria e Editora Marcello de Ipanema, Rio de Janeiro, 1991, p. 37.

30 Viagens como as de Rodrigo Acuña e de João Dias de Solis, se bem que não sejam provas cabais de presença européia e de conhecimento português das paragens da Baía de Guanabara, trazem elementos indiciatórios de certa importância que permitem perfilá-los entre as informações de proveito.

A carta a Carlos V, passada por Luiz Ramirez em 1528, estampa a notícia de que chegara, em Setembro de 1526, a "una isla parecia tras a una grande montaña", situada numa região que aparentava "ser abundante em pau-brasil e que soubera da existência, no meio dos índios, de vários espanhóis que ali tinham ficado quando a armada de D. Rodrigo Acuña voltara à Espanha», conforme transcrição e comentário de Veríssimo Serrão.

Herrera, na "Historia General», investe na garantia de que Solis, ao balizar a posição do Cabo Frio, inflectira o curso para o Rio de Janeiro onde lançou ferros, após um longo trajeto que se iniciara em San Lucar de Barrameda, no mês de Outubro de 1515. Não se pode deixar de notar, na descrição do sítio de ancoragem de Luiz Ramirez, sua natural parecença com um hipotético (e possível) fundeadouro ao abrigo da Ilha do Governador, "tras una grande montaña" e em meio a uma flora exuberante, a Mata Atlântica viabilizadora do pau-brasil. Uma vez mais, a ilha.

31 O Rio de Janeiro no século XVI (documentos dos arquivos portugueses), Comissão Nacional das Comemorações do IV Centenário do Rio de Janeiro, Lisboa, 1965, p.47, v. 2. 
Convém recordar que Pero Lopes de Souza, no "Diário», dá conta de que, ao entrar em Pernambuco, encontrara o feitor local ausente, o qual tinha viajado ao Rio de Janeiro numa caravela portuguesa em rota para Sofala. Isto mostra existir na Guanabara condições muito especiais, embora não se saiba quais sejam exatamente, para facultar deslocamentos como o do agente comercial e escalas de refresco ou resgates de produtos da flora tropical. Mais cedo, ainda, em 13 de Dezembro de 1519, a frota espanhola comandada por Fernão de Magalhães, deita ferros da Guanabara. A baía, entretanto, é designada como "porto de Santa Luzia», em homenagem à efeméride da data.

32 Esta iniciativa não pode ser considerada gratuita ou divorciada do elenco de providências estabelecidas (e, portanto, previamente projetadas para a escala) para serem concretizadas no Rio de Janeiro e que estão descritas no "Diário» de Pero Lopes de Souza.

Ressuprir a frota de alimentos para quatrocentos homens durante um ano, não é medida que se tome sem uma prévia avaliação de suas reais possibilidades de atendimento, quando e onde. Sob este aspecto, torna-se patente o prévio e amiudado conhecimento do local da escala e de suas potencialidades logísticas para suportar o abastecimento de porão e da estadia de três meses.

33 Cybelle de Ipanema descreve meticulosamente as nascentes da Ilha (obra citada, pp. 39 e 40).

34 Ver a referido trabalho de Cybelle de Ipanema, pp. 184 e 188.

35 As pesquisas arqueológicas levadas a cabo no Rio de Janeiro por instituições brasileiras públicas e privadas - Museu Nacional, Instituto do Patrimônio Histórico e Artístico Nacional, Centro Brasileiro de Arqueologia e Instituto de Arqueologia Brasileira - e estrangeiras , desenvolveram ao longo de vinte anos, a partir da década de 60, intensos programas de estudos prospectivos e de formação de acervos de testemunhos, principalmente, cerâmicos e líticos, onde se destacam as atividades de Ondemar Ferreira Dias Junior e de Maria Beltrão, esta última produzindo expressiva bibliografia técnica e de divulgação. Dessa forma, a ausência até ali de pesquisas arqueológicas, ao que se presume, obscureceu um caminho importante para a recuperação da história do Rio de Janeiro nos anos arrimados ao primeiro terço do século xvi e para a confirmação da presença lusa na Guanabara no primeiro quarto dessa mesma centúria.

36 Cfr. Cybelle de Ipanema, obra citada, p. 55.

37 HNB, v. 1, t. 1, pp. 414 a 434. 
38 Os grandes anos do comércio francês iniciam-se em 1530 e ampliam-se muito a partir de 1541, e de 1546 a 1549. A fase "Cabo Frio" é a dos meados do século. Em 1541, três ou quatro zonas ou pontos, na costa brasileira, serviam para garantir aos franceses os suprimentos de produtos tropicais especialmente o $\mathrm{PB}$, de preparo demorado: Paraíba, Pernambuco, Baía de Todos os Santos e Rio de Janeiro, este último, provavelmente, a partir de 1546, segundo Luís de Góis.

Essas regiões continuaram sendo visitadas, pelo menos, nos vinte anos seguintes. Da década de setenta, em diante, os contatos dão-se de Cabo Frio para cima, com Pernambuco fornecendo um PB de enorme reputação entre os franceses, o "bois de Fernambouc».

39 Pré-história do Estado do Rio de Janeiro, Editora Forense Universitária, Rio de Janeiro, 1978, pp. 136 e 137

40 As justaposições das faixas a "períodos franceses" são muito mais estreitas do que a épocas de contactos, desembarques, estadias e ocupação portuguesa, entre 1500 e 1600, limites das datações. Sob o enfoque matemático, as possibilidades de serem francesas as influências detectadas na Ilha do Gato vão, a bem dizer, de pequenas a muito pequenas.

41 Ver A Primeira feitoria portuguesa no Brasil, de Fernando Lourenço Fernandes; Academia de Marinha, Lisboa, 1996, pp. 38 e 39. Comunicação apresentada em 22/10/96.

42 Grande parte dos sítios arqueológica da Ilha do Governador encontra-se em áreas jurisdicionadas pela Marinha. Devido ao tipo de ocupação desses espaços (que os manteve afastados da intensiva exploração imobiliária) diversos núcleos de jazimentos quedaram-se resguardados, permitindo os trabalhos de investigação aqui descritos. Embora intrusões e erosões antropogênicas tenham ocorrido em vários pontos, há porém locais, conforme constatou o autor do presente trabalho, ainda não totalmente descaracterizados para pesquisas da pré e da proto-história da ilha do Gato e do Rio de Janeiro e que se encontram nas áreas de matas (secundárias) preservadas pela Marinha e nas praias adjacentes.

Artigo recebido em 03/2008. Aprovado em 07/2008. 